\title{
THE ENTRY OF $\alpha$-CHLOROHYDRIN INTO BODY FLUIDS OF MALE RATS AND ITS EFFECT UPON THE INCORPORATION OF GLYCEROL INTO LIPIDS
}

\author{
ELIZABETH M. EDWARDS,* A. R. JONES $\dagger$ AND \\ G. M. H. WAITES* \\ * Department of Physiology EO Biochemistry, \\ The University, Whiteknights, Reading RG6 2AJ, and \\ $\dagger$ Department of Pharmacology, University of Manchester, \\ Manchester M13 9PL
}

\section{(Received 7th August 1974)}

\begin{abstract}
Summary. The rate of entry of $\alpha$-chlorohydrin into rat rete testis fluid has been studied using the ${ }^{14} \mathrm{C}$ - and ${ }^{36} \mathrm{Cl}$-labelled compound. The $\alpha$-chlorohydrin crossed the blood-testis barrier and the concentration of radioactivity in rete testis fluid attained blood levels within $45 \mathrm{~min}$. Within $3 \mathrm{hr}$ of a single injection of $\left[{ }^{14} \mathrm{C}\right] \alpha$-chlorohydrin, radioactivity was widely distributed in body fluids, and was present in the lipids of the brain, testis, epididymis and epididymal fat pads. No radioactivity was found in tissue lipids following the administration of $\left[{ }^{36} \mathrm{Cl}\right] \alpha$-chlorohydrin, which suggests that dechlorination of this compound occurs before its incorporation. Neither a single high dose nor repeated low doses of $\alpha$-chlorohydrin induced changes in the incorporation of $\left[{ }^{14} \mathrm{C}\right]$ glycerol into lipids of the brain, testis, epididymis and epididymal fat pad.
\end{abstract}

\section{INTRODUGTION}

Studies with the antifertility agent, $\alpha$-chlorohydrin (3-chloro-1,2 propanediol) have indicated that this compound has at least two sites of action in the male rat. When given at high doses, it produces characteristic lesions in the caput epididymidis, leading to an occlusion of the epididymal duct and subsequent degeneration of the germinal epithelium (Ericsson, 1970; Hoffer, Hamilton \& Fawcett, 1973; Cooper, Jones \& Jackson, 1974). At lower doses, this effect is not seen but a functional interference with spermatozoa occurs, causing a reversible phase of sterility (Coppola, 1969; Gunn, Gould \& Anderson, 1969; Vickery, Erickson \& Bennett, 1974). In view of this apparent dual action, it was decided to investigate the route and rates of entry of $\alpha$-chlorohydrin into the reproductive tract of the male rat.

The primary site of action of $\alpha$-chlorohydrin is as yet unknown. Coppola (1969) and Gunn et al. (1969) suggested that the action of $\alpha$-chlorohydrin depended on its structural similarity to glycerol. We have therefore studied 
the effects of both high and low doses of $\alpha$-chlorohydrin on the incorporation of $\left[{ }^{14} \mathrm{C}\right]$ glycerol into lipids. The possibility that $\alpha$-chlorohydrin itself becomes incorporated into lipids has also been explored by the use of both $\left[{ }^{14} \mathrm{C}\right]-$ and $\left[{ }^{36} \mathrm{Cl}\right] \alpha$-chlorohydrin. Part of this work has already been reported in preliminary form (Edwards, Jones \& Waites, 1973).

\section{MATERIALS AND METHODS}

\section{Animals}

Thirty-four sexually mature male rats (CSE/1;250 to $350 \mathrm{~g}$ body weight; Manston Research Centre, Margate, Kent) were used. They were fed pellets (Diet 86: Dixon \& Sons (Ware) Ltd) and allowed water without restriction.

\section{Chemicals}

Glycidol (2,3-epoxypropanol) and $\alpha$-chlorohydrin (3-chloro-1,2 propanediol) were obtained from B.D.H. Chemicals (Poole) Ltd, and purified by distillation under reduced pressure.

\section{Radioactive compounds}

Uniformly labelled $\left[{ }^{14} \mathrm{C}\right.$ ]glycerol (approximately $20 \mathrm{mCi} / \mathrm{mmol}$ ) was obtained from the Radiochemical Centre, Amersham, Bucks. The uniformly labelled $\left[{ }^{14} \mathrm{C}\right] \alpha$-chlorohydrin (sp. act. $72 \mu \mathrm{Ci} / \mathrm{mmol}$ ) was prepared by the method of Jones (1973), and the $\left[{ }^{36} \mathrm{Cl}\right] \alpha$-chlorohydrin (sp. act. $16 \mu \mathrm{Ci} / \mathrm{mmol}$ ) was synthesized from $\mathrm{H}^{36} \mathrm{Cl}$ (Radiochemical Centre, Amersham, Bucks) and glycidol.

\section{Surgical procedures}

Seven rats were anaesthetized with halothane (Fluothane: I.C.I., Macclesfield, Cheshire) -oxygen, the testes were exposed through a mid-line abdominal incision and the ductuli efferentes were ligated. The rats were anaesthetized with sodium pentobarbitone (Nembutal: Abbott Laboratories, Queensborough, Kent) 18 to $24 \mathrm{hr}$ later and samples of rete testis fluid were obtained by a method which has been previously described (Tuck, Setchell, Waites \& Young, 1970; Waites, Jones, Main \& Cooper, 1973). Blood samples were collected through a polyvinyl chloride cannula $(0.5 \mathrm{~mm}$ i.d., $0.8 \mathrm{~mm}$ o.d.) inserted into one carotid artery. Terminal samples of cerebrospinal fluid were collected into tapered glass capillary tubes inserted into the cisterna magna, and seminal vesicle fluid into capillary tubes introduced into the cavity of the seminal vesicles. Other samples were obtained from the cauda epididymidis and the ductus deferens by severing the ducts and gently squeezing their contents into capillary tubes.

\section{Experimental procedures}

Entry of $\alpha$-chlorohydrin into body fuids. The ${ }^{14} \mathrm{C}$ - or ${ }^{36} \mathrm{Cl}$-labelled $\alpha$-chlorohydrin dissolved in $0.9 \%$ (w/v) NaCl, was administered by intraperitoneal injection, usually immediately after the successful cannulation of one rete testis.

Incorporation of $\left[{ }^{14} C\right]$ - and $\left[{ }^{36} C l\right] \alpha$-chlorohydrin into lipids. Each of the radio- 
active compounds (100 $\mathrm{mg} / \mathrm{kg}$ body weight) dissolved in 0.5 to $0.75 \mathrm{ml} 0.9 \%$ $(\mathrm{w} / \mathrm{v}) \mathrm{NaCl}$ was injected into the exposed jugular vein of two rats anaesthetized with sodium pentobarbitone, care being taken to avoid any loss from the blood stream by bleeding. The rats were killed $3 \mathrm{hr}$ later by an overdose of the anaesthetic and the brain, testes, epididymides and epididymal fat pads were removed. The epididymides were divided into two segments, the caput plus corpus and the cauda, and the capsules were removed from the testes. All tissues were weighed into chilled vessels and frozen to await lipid extraction.

Incorporation of $\left[{ }^{14} \mathrm{C}\right]$ glycerol into lipids after a single high dose of $\alpha$-chlorohydrin. The $\left[{ }^{14} \mathrm{C}\right]$ glycerol $(25$ to $50 \mu \mathrm{Ci})$ dissolved in 0.5 to $0.75 \mathrm{ml} 0.9 \%(\mathrm{w} / \mathrm{v}) \mathrm{NaCl}$ was injected directly into the exposed jugular vein of six rats anaesthetized with sodium pentobarbitone and the skin incision was closed by sutures. The rats had been given either $0.9 \%(\mathrm{w} / \mathrm{v}) \mathrm{NaCl}$ or $\alpha$-chlorohydrin $(100 \mathrm{mg} / \mathrm{kg}$ body weight) intraperitoneally $5 \mathrm{~min}$ before the injection of the radioactive glycerol. The rats were killed $3 \mathrm{hr}$ later with an overdose of the anaesthetic and, as before, tissues were removed, weighed and frozen to await lipid extraction.

Incorporation of $\left[{ }^{14} \mathrm{C}\right]$ glycerol into lipids after long-term low daily doses of $\alpha$-chlorohydrin. Ten rats were given daily doses $(6.5 \mathrm{mg} / \mathrm{kg}$ body weight) of $\alpha$-chlorohydrin dissolved in water. The dose was administered by oesophageal tube, and the volume given was less than $1 \mathrm{ml}$. Five control rats were given an equivalent volume of water per day. One control and two experimental rats were anaesthetized with sodium pentobarbitone after 2,4 and 6 weeks of treatment, and the remaining rats after 22 weeks of treatment. The $\left[{ }^{14} \mathrm{C}\right]$ glycerol $(25 \mu \mathrm{Ci})$ was injected into the jugular vein as described above. The rats were killed $3 \mathrm{hr}$ later by an overdose of the anaesthetic and tissues were again removed, weighed and frozen.

\section{Lipid extraction}

Lipids were extracted from the tissues with chloroform:methanol $(2: 1 \mathrm{v} / \mathrm{v})$ and washed with isotonic $0.37 \% \mathrm{KCl}(\mathrm{w} / \mathrm{v})$, following the method described by Folch, Lees \& Sloane Stanley (1957). The lipid extract was taken to dryness under a stream of nitrogen and dissolved in a known volume of $2: 1(\mathrm{v} / \mathrm{v})$ chloroform: methanol. Aliquots were taken for scintillation counting.

\section{Thin-layer chromatography}

Thin-layer chromatography of body fluid samples was performed on precoated silica gel G plates (E. Merck, Anderman \& Co. Ltd, London) using butanol saturated with water as solvent.

The separation of neutral lipids from phospholipids was carried out on silica gel G plates (Mallinkrodt, Camlab, Cambridge) using $60^{\circ}$ to $80^{\circ}$ petroleum ether: diethyl ether:acetic acid (90:10:1 by vol.) as solvent. Separation of individual lipid fractions was made with a two solvent system: Solvent 1, chloroform:methanol: water (59:39:2 by vol.); Solvent 2, 100\% chloroform. These separations were made on pre-coated Kieselgel $60 \mathrm{~F}$ plates (E. Merck, Anderman \& Co. Ltd, London).

Lipids were detected by exposure to iodine vapour and ultraviolet light. Spots which were identified by comparison with standard lipids were scraped 
from the plates into scintillation vials and the radioactivity present was subsequently estimated.

\section{Scintillation counting}

The scintillation fluid used was toluene: Triton X-100 (Packard Instrument Co. Inc., Illinois, U.S.A.) containing $2.0 \mathrm{~g}$ PPO and $0.25 \mathrm{~g}$ POPOP per litre. The radioactivity was counted in a liquid scintillation spectrometer (Nuclear Enterprises Ltd, NE8310, Edinburgh, Scotland) and corrected to $100 \%$ by use of an external standard quench correction.

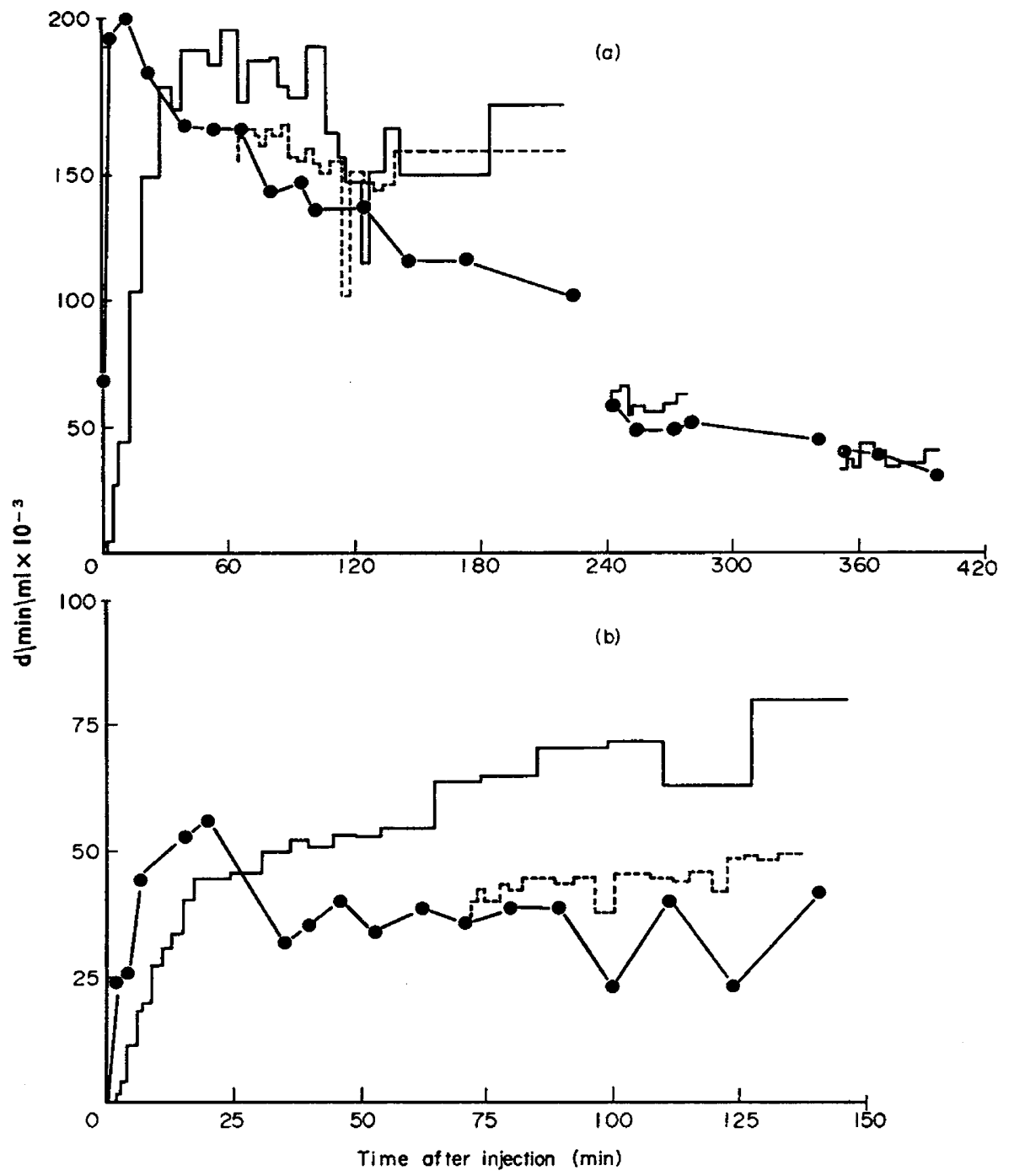

TEXT-FrG. 1. Entry of $\alpha$-chlorohydrin into the blood and rete testis fluid of rats after intraperitoneal injection (100 mg/kg body weight) of (a) $\left[{ }^{14} \mathrm{C}\right] \alpha$-chlorohydrin; (b) $\left[{ }^{36} \mathrm{Cl}\right] \alpha$-chlorohydrin. Radioactivity $\left(\mathrm{d} / \mathrm{min} / \mathrm{ml} \times 10^{-3}\right)$ in arterial blood $(\bullet)$, left rete testis fluid $(-)$ and right rete testis fluid $(--)$. 


\section{RESULTS}

The entry of $\left[{ }^{14} \mathrm{C}\right]$ - and $\left[{ }^{36} \mathrm{Cl}\right] \alpha$-chlorohydrin into body fluids

After a single intraperitoneal injection of $\left[{ }^{14} \mathrm{C}\right]$ - and $\left[{ }^{36} \mathrm{Cl}\right] \alpha$-chlorohydrin $(100 \mathrm{mg} / \mathrm{kg}$ body weight $)$, the radioactivity in rete testis fluid rose rapidly and reached levels similar to those found in blood within $45 \mathrm{~min}$ (Text-fig. 1). Thin-layer chromatography of blood plasma and rete testis fluid showed that radioactivity in these samples appeared in one main peak, with an $R_{\mathrm{F}}$ corresponding to that of $\alpha$-chlorohydrin. When cannulation of the rete testis was delayed until 4 to $6 \mathrm{hr}$ after the injection of $\left[{ }^{14} \mathrm{C}\right] \alpha$-chlorohydrin, levels of radioactivity were again similar to those in the blood, although by this time the radioactivity in blood and rete testis fluid had fallen.

The radioactivity in various body fluids $3 \mathrm{hr}$ after intraperitoneal injection of $\left[{ }^{14} \mathrm{C}\right] \alpha$-chlorohydrin varied widely when expressed as a ratio of that in blood. This ratio for cerebrospinal fluid (1.02 \pm 0.06 [4]; mean \pm S.E.M. [number of observations]), rete testis fluid $(1 \cdot 24 \pm 0 \cdot 12$ [5]) and the contents of the cauda epididymidis $(0 \cdot 79 \pm 0 \cdot 14$ [7]) did not differ significantly from 1 . By contrast, the concentration of radioactivity in the seminal vesicle contents was significantly lower than that in the blood $(0.63 \pm 0.02$ [4]) and the contents of the ductus deferens contained very low amounts of radioactivity $(0.03 \pm 0.02$ [5]) at this time.

\section{The incorporation of $\left[{ }^{14} \mathrm{C}\right]$ - and $\left[{ }^{36} \mathrm{Cl}\right] \alpha$-chlorohydrin into lipids}

Following intravenous injection into two rats of $\left[{ }^{14} \mathrm{C}\right] \alpha$-chlorohydrin (100 mg/kg body weight), radioactivity was found in the lipids of the brain, testes, the combined caput and corpus epididymidis, cauda epididymidis and epididymal fat pad. In all tissues, less than $10 \%$ of the radioactivity was due to unchanged $\alpha$-chlorohydrin.

In similar experiments with $\left[{ }^{36} \mathrm{Cl}\right] \alpha$-chlorohydrin, radioactivity was found in the lipid extract of every tissue except the epididymal fat pad. Thin-layer chromatography showed that this radioactivity was associated with one component with the same $R_{\mathrm{F}}$ as $\alpha$-chlorohydrin. It appeared that no ${ }^{36} \mathrm{Cl}$ had become incorporated into lipid components in these tissues.

\section{The effects of $\alpha$-chlorohydrin on the incorporation of $\left[{ }^{14} \mathrm{C}\right]$ glycerol into lipids}

Single high dose of $\alpha$-chlorohydrin ( $100 \mathrm{mg} / \mathrm{kg}$ body weight). The extent of incorporation of glycerol into lipids in the tissues of male rats was variable (Table 1). The administration of inactive $\alpha$-chlorohydrin $5 \mathrm{~min}$ before the intravenous injection of $\left[{ }^{14} \mathrm{C}\right]$ glycerol did not appear to alter glycerol incorporation into lipids in the testes, epididymides, brain and epididymal fat pads $3 \mathrm{hr}$ later. In the tissues of the reproductive tract that were studied, the highest rate of incorporation of glycerol into lipids was in the caput plus corpus epididymidis.

The percentage of radioactivity incorporated into neutral lipids $3 \mathrm{hr}$ after intravenous injection of $\left[{ }^{14} \mathrm{C}\right]$ glycerol was variable between animals but was apparently unchanged by pretreatment with $\alpha$-chlorohydrin (Table 1). The percentage of the radioactivity in the caput plus corpus epididymidis from two of the $\alpha$-chlorohydrin treated rats $(85 \%$ and $79 \%$ ), however, was considerably higher than that found in the controls. 
Table 1. The effect of $\alpha$-chlorohydrin on radioactivity in tissue lipids from rats $3 \mathrm{hr}$ after intravenous injection of $100 \mathrm{mg}\left[{ }^{14} \mathrm{C}\right] \mathrm{glycerol} / \mathrm{kg}$ body weight

\begin{tabular}{|c|c|c|c|c|}
\hline & \multicolumn{2}{|c|}{$\begin{array}{c}\text { Total radioactivity } \\
\left(\text { dimin } / \mathrm{g} \text { per d/min injected } \times 10^{6}\right)\end{array}$} & \multicolumn{2}{|c|}{$\begin{array}{l}\% \text { Radioactivity } \\
\text { in neutral lipids }\end{array}$} \\
\hline & $\begin{array}{c}\text { Saline } \\
\text { pretreated }\end{array}$ & $\begin{array}{c}\alpha-C h l o r o h y d r i n \\
\text { pretreated }\end{array}$ & $\begin{array}{c}\text { Saline } \\
\text { pretreated }\end{array}$ & $\begin{array}{c}\alpha \text {-Chlorohydrin } \\
\text { pretreated }\end{array}$ \\
\hline $\begin{array}{l}\text { Brain } \\
\text { Testis } \\
\text { Caput plus corpus epididymidis } \\
\text { Cauda epididymidis } \\
\text { Epididymal fat pad }\end{array}$ & $\begin{array}{l}180 \pm 91 \\
131 \pm 47 \\
3372 \pm 89 \\
155 \pm 19 \\
620 \pm 159\end{array}$ & $\begin{array}{l}212 \pm 70 \\
143 \pm 62 \\
465 \pm 138 \\
169 \pm 48 \\
728 \pm 326\end{array}$ & $\begin{array}{l}27 \cdot 7 \pm 9 \cdot 7 \\
55 \cdot 7 \pm 6 \cdot 4 \\
48 \cdot 0 \pm 4 \cdot 1 \\
45 \cdot 3 \pm 4 \cdot 9 \\
93 \cdot 1 \pm 1 \cdot 8\end{array}$ & $\begin{array}{l}31 \cdot 3 \pm 9 \cdot 8 \\
53 \cdot 3 \pm 3 \cdot 7 \\
71 \cdot 3 \pm 10 \cdot 8 \\
55 \cdot 3 \pm 3 \cdot 3 \\
94 \cdot 0 \pm 2 \cdot 1\end{array}$ \\
\hline
\end{tabular}

Values represent Means \pm S.E.M.; three rats in each group.

Long-term daily treatment with a low dose of $\alpha$-chlorohydrin $(6.5 \mathrm{mg} / \mathrm{kg}$ body weight). Long-term treatment with $\alpha$-chlorohydrin (2, 4, 6 and 22 weeks) at a low dose did not significantly alter either the total amount of $\left[{ }^{14} \mathrm{C}\right]$ glycerol incorporated into lipids or the proportion of this radioactivity which was present in neutral lipids. A more detailed analysis of the incorporation of $\left[{ }^{14} \mathrm{C}\right]$ glycerol into individual lipid fractions in animals treated with $\alpha$-chlorohydrin for 22 weeks is given in Table 2. There were no major differences between test and control animals; the over-all pattern of incorporation was similar in the testes and both sections of the epididymides. Both in the testes and the epididymides, the principal incorporation was into phosphatidyl choline and triglycerides.

Table 2. Percentage distribution of $\left[{ }^{14} \mathrm{C}\right]$ glycerol in the lipids of rats after daily oral dosing for 22 weeks with a low dose of $6.5 \mathrm{mg} \alpha$-chlorohydrin/ $/ \mathrm{kg}$ body weight

\begin{tabular}{|c|c|c|c|c|c|c|}
\hline \multirow{2}{*}{ Component } & \multicolumn{2}{|c|}{ Testes } & \multicolumn{2}{|c|}{$\begin{array}{c}\text { Caput+ } \\
\text { corpus epididymidis }\end{array}$} & \multicolumn{2}{|c|}{ Cauda epididymidis } \\
\hline & $\begin{array}{l}\text { Test } \\
(4)\end{array}$ & $\begin{array}{c}\text { Control } \\
(2)\end{array}$ & $\begin{array}{l}\text { Test } \\
(4)\end{array}$ & $\begin{array}{l}\text { Control } \\
(2)\end{array}$ & $\begin{array}{l}\text { Test } \\
(4)\end{array}$ & $\begin{array}{l}\text { Control } \\
\text { (1) }\end{array}$ \\
\hline $\begin{array}{l}\text { Phosphatidyl choline } \\
\text { Phosphatidyl serine } \\
\text { Phosphatidyl inositol } \\
\text { Phosphatidyl ethanolamine } \\
\text { Diglycerides } \\
\text { Triglycerides }\end{array}$ & $\begin{array}{r}23 \cdot 5 \pm 1 \cdot 5 \\
8 \cdot 5 \pm 1 \cdot 7 \\
5 \cdot 0 \pm 0 \cdot 7 \\
13 \cdot 0 \pm 1 \cdot 4 \\
9 \cdot 5 \pm 1 \cdot 4 \\
19 \cdot 8 \pm 1 \cdot 0\end{array}$ & $\begin{array}{r}23 \cdot 5 \pm 2 \cdot 5 \\
8 \cdot 5 \pm 2 \cdot 5 \\
4 \cdot 5 \pm 0.5 \\
18 \cdot 0 \pm 1 \cdot 0 \\
8 \cdot 5 \pm 1 \cdot 5 \\
16 \cdot 0 \pm 2 \cdot 0\end{array}$ & $\begin{array}{r}28 \cdot 0 \pm 1 \cdot 5 \\
11 \cdot 0 \pm 1 \cdot 1 \\
2 \cdot 8 \pm 0 \cdot 6 \\
10 \cdot 0 \pm 0 \cdot 6 \\
18 \cdot 3 \pm 3 \cdot 0 \\
20 \cdot 0 \pm 5 \cdot 2\end{array}$ & $\begin{array}{r}28 \cdot 5 \pm 1 \cdot 5 \\
10 \cdot 5 \pm 3 \cdot 5 \\
5 \cdot 5 \pm 1 \cdot 5 \\
10 \cdot 5 \pm 0.6 \\
15 \cdot 0 \pm 4 \cdot 0 \\
18 \cdot 5 \pm 0.5\end{array}$ & $\begin{array}{r}24 \cdot 5 \pm 1 \cdot 9 \\
12 \cdot 3 \pm 1 \cdot 0 \\
6 \cdot 0 \pm 1 \cdot 1 \\
7 \cdot 3 \pm 0 \cdot 9 \\
9 \cdot 0 \pm 2 \cdot 3 \\
23 \cdot 0 \pm 2 \cdot 0\end{array}$ & $\begin{array}{r}29 \cdot 7 \\
9 \cdot 3 \\
5 \cdot 2 \\
5 \cdot 2 \\
8 \cdot 1 \\
22 \cdot 7\end{array}$ \\
\hline
\end{tabular}

Values represent the Mean percentage \pm S.E.M. The numbers of rats in each group are given in parentheses.

\section{DISCUSSION}

The antifertility compound, $\alpha$-chlorohydrin, rapidly enters the body fluids of the rat following intraperitoneal administration. The blood concentration quickly rises and the compound is able to cross the blood-testis barrier to enter the rete testis fluid, attaining blood levels within $45 \mathrm{~min}$. The concentration of radioactivity in cerebrospinal fluid $3 \mathrm{hr}$ after the injection of $\left[{ }^{14} \mathrm{C}\right] \alpha-$ 
chlorohydrin was also similar to that found in the blood, demonstrating its free transfer across the blood-brain barrier. The penetration of $\alpha$-chlorohydrin into the central nervous system may be responsible for the neural disturbances in male mice treated with high daily doses of this compound (Samojlik \& Chang, 1970). Preliminary results obtained in this laboratory indicate that radioactivity can be recovered from brain lipids of mice treated with $\left[{ }^{14} \mathrm{C}\right] \alpha$ chlorohydrin.

Three hours after its administration, $\alpha$-chlorohydrin is present not only in the lumen of the cauda epididymidis of the rat, but also in the rete testis fluid, which suggests that spermatozoa of treated rats are exposed to the compound from the time they are shed from the germinal epithelium up to the moment of ejaculation. Our finding that levels of radioactivity in the seminal vesicle contents were $63 \%$ of those in the blood confirms that ejaculated spermatozoa and the female reproductive tract are also exposed to this compound. The absence of the radioactive compound in the contents of the ductus deferens of the rat is rather surprising in view of the rapid appearance of radioactivity in other body fluids. Radioactive $\alpha$-chlorohydrin was not specifically concentrated within the reproductive tract $3 \mathrm{hr}$ after its administration. This does not necessarily contradict the findings of Crabo \& Appelgren (1972) who demonstrated that radioactivity accumulated within the cauda epididymidis of the rat 4 days after the administration of $\left[{ }^{14} \mathrm{C}\right] \alpha$-chlorohydrin.

Significant amounts of radioactivity were found in lipid extracts of tissues from animals treated $3 \mathrm{hr}$ previously either with $\left[{ }^{14} \mathrm{C}\right]$ - or $\left[{ }^{36} \mathrm{Cl}\right] \alpha$-chlorohydrin. When the ${ }^{36} \mathrm{Cl}$-compound was administered, this activity was due solely to unaltered $\alpha$-chlorohydrin. When the ${ }^{14} \mathrm{C}$-compound was administered, however, radioactivity was found in a number of glyceride fractions. This indicates that $\alpha$-chlorohydrin undergoes modification by a dechlorination process before being utilized in lipid synthesis. The modifications might involve conversion of $\alpha$-chlorohydrin to the epoxide glycidol (Jackson, Campbell \& Jones, 1970 ), or hydrolysis of $\alpha$-chlorohydrin to glycerol. Direct incorporation of $\alpha$ chlorohydrin into lipids followed by immediate dechlorination would give a similar distribution pattern of both radioactive labels, although this mechanism is thought to be unlikely.

Due to its structural similarity to glycerol, many workers have suggested that $\alpha$-chlorohydrin might exert its antifertility action through an interference with the metabolism of glycerol in the reproductive tract. To our knowledge, only Hodgen (1972) has attempted to investigate this proposition. He showed that total amounts of glycerol in the testis, epididymis and ductus deferens of the rat were unaffected by $\alpha$-chlorohydrin treatment. We have also been unable to demonstrate any consistent effect of $\alpha$-chlorohydrin on the incorporation of glycerol into lipids in the brain, epididymal fat pad and reproductive tract either shortly after the administration of a high dose of $\alpha$-chlorohydrin or after daily treatment with low doses for periods up to 22 weeks. As the incorporation of glycerol into tissue lipids was variable from animal to animal, however, and the amounts of radioactivity incorporated were low, it is difficult to assert with certainty that $\alpha$-chlorohydrin was completely without effect on the incorporation of glycerol. This is especially true since whole tissues were 
analysed in this study and the effect of the compound may be specifically upon spermatozoa.

The possibility remains that $\alpha$-chlorohydrin or its metabolites exert their effects by interfering with the metabolism of glycerol by a pathway independent of lipid synthesis.

\section{ACKNOWLEDGMENTS}

The authors thank Mr T. Pearson and Mrs I. Spokes who cared for the animals and administered the daily oral doses of $\alpha$-chlorohydrin. We also acknowledge the technical assistance of Mr R. J. Parrott. This work was supported by grants from the Population Council, New York, the Medical Research Council and the World Health Organization. The Nuclear Enterprises NE 8310 scintillation counter was purchased with M.R.G. grant G971/252/B to the Department of Physiology \& Biochemistry, University of Reading.

\section{REFERENCES}

COOPER, E. R. A., JoNES, A. R. \& JACKSON, H. (1974) Effects of $\alpha$-chlorohydrin and related compounds on the reproductive organs and fertility of the male rat. F. Reprod. Fert. 38, 379-386.

Coppola, J. A. (1969) An extragonadal male antifertility agent. Life Sci. 8, 43-48.

CRABo, B. \& Appelgren, L.-E. (1972) Distribution of $\left[{ }^{14} \mathrm{C}\right] \alpha$-chlorohydrin in mice and rats. F. Reprod. Fert. 30, 161-163.

Edwards, E. M., Jones, A. R. \& Waites, G. M. H. (1973) The action of $\alpha$-chlorohydrin (3-chloropropane 1,2-diol) on the metabolism of glycerol in male rats. F. Reprod. Fert. 35, 589-590.

ERICsson, R. J. (1970) Male antifertility compounds: U-5897 as a rat chemosterilant. J. Reprod. Fert. 22, 213-222.

Folch, J., Lees, M. \& Sloane Stanley, G. H. (1957) A simple method for the isolation and purification of total lipids from animal tissues. F. biol. Chem. 226, 497-509.

Gunn, S. A., Gould, T. G. \& Anderson, W. A. D. (1969) Possible mechanism of post-testicular antifertility action of 3-chloro 1-2 propanediol. Proc. Soc. exp. Biol. Med. 132, 656-659.

Hodgen, G. D. (1972) Total glycerol in the excurrent ducts of the male rat. J. Reprod. Fert. 28, 277-280.

Hofper, A. P., Hamilton, D. W. \& FawcetT, D. W. (1973) The ultrastructural pathology of the rat epididymis after administration of $\alpha$-chlorohydrin (U-5897). 1. Effects of a single high dose. Anat. Rec. 175, 203-230.

Jackson, H., Gampbell, I. S. C. \& Jones, A. R. (1970) Is glycidol an active intermediate in the antifertility action of $\alpha$-chlorohydrin in male rats? Nature, Lond. 226, 86-87.

JonEs, A. R. (1973) The synthesis of ${ }^{14} \mathrm{C}$-3-chloro-, 3-bromo- and 3-iodo-propan-1,2-diol and 2,3epoxypropan-1-ol. F. Labelled Cpds, 9, 697-701.

Samojuk, E. \& Chanc, M. C. (1970) Antifertility activity of 3-chloro-1,2-propanediol (U-5897) on male rats. Biol. Reprod. 2, 299-304.

Tuck, R. R., Setchell, B. P., Wartes, G. M. H. \& Young, J. A. (1970) The composition of fluid collected by micropuncture and catheterization from the seminiferous tubules and rete testis of rats. Pfügers Arch. ges. Physiol. 318, 225-243.

Vickery, B. H., ERickson, G. I. \& BenNETt, J. P. (1974) Mechanism of antifertility action of low doses of $\alpha$-chlorohydrin in the male rat. F. Reprod. Fert. 38, 1-10.

Waites, G. M. H., Jones, A. R., MaIN, S. J. \& Cooper, T. G. (1973) The entry of antifertility and other compounds into the testis. Adv. Biosci. 10, 101-116. 